\title{
STABILITAS LAPIS ASPAL BETON AC-WC MENGGUNAKAN ABU SEKAM PADI
}

\author{
Said Jalalul Akbar ${ }^{1)}$, Wesli ${ }^{2)}$ \\ Jurusan Teknik Sipil Universitas Malikussaleh \\ email: jaakidani@gmail.com ${ }^{1)}$,ir_wesli@yahoo.co.id ${ }^{2)}$
}

\begin{abstract}
Abstrak
AC-WC (Asphal Concrete-Wearing Course) merupakan lapis aspal beton (laston) yang berfungsi sebagai lapisan aus pada sebuah konstruksi perkerasan jalan. Sebagai bahan pengisi pada lapis ini biasanya digunakan abu batu. Pada penelitian ini dilakukan alternatif pengganti bahan pengisi yaitu dengan menggunakan abu sekam padi yang diambil dari limbah hasil pembakaran pada kilang padi. Tujuan penelitian ingin mengetahui seberapa besar perbedaan nilai para meter marshall antara abu batu dengan abu sekam padi sebagai pengganti filler pada campuran aspal panas AC-WC. Metode yang digunakan adalah metode bina marga, dengan membuat benda uji dari kedua campuran sesuai syarat Depkimpraswil (2002) dengan beberapa variasi tertentu, selanjutnya dilakukan pengujian Marshall dilaboratorium. Penelitian ini hanya melihat perbedaan nilai parameter Marshall antara abu batu dengan abu sekam padi.Dari hasil pengujian yang telah dilakukan di laboratorium diporeh nilai parameter marshall sebagai berikut: nilai Density, Stabilitas, Flow dan Marshall Quotient meningkat (lebih besar) pada campuran yang menggunakan abu sekam padi. Kenaikan nilai Density, Stabilitas, Flow dan Marshall Quotient secara merata (optimum) terjadi pada campuran yang menggunakan abu sekam padi 6\%. Sedangkan pada campuran abu sekam padi $8 \%$ terjadi penurunan nilai stabilitas.
\end{abstract}

Kata kunci: Stabilitas, Laston, Abu Sekam Padi

\section{Pendahuluan}

AC-WC (Asphal Concrete-Wearing Course) merupakan lapis aspal beton (laston) yang berfungsi sebagai lapisan aus pada sebuah konstruksi perkerasan jalan. Tebal nominal minimum biasanya adalah $4 \mathrm{~cm}$. AC-WC Multigrade merupakan salah satu implementasi perkembangan teknologi hot mix di Indonesia, dan sangat cocok untuk jalan raya dengan lalu lintas berat dan padat. Untuk dapat memikul beban tertentu, suatu material perkerasan harus mempunyai kekuatan (strength) atau modulus tertentu dan untuk mencapai kekuatan tertentu tersebut, material yang merupakan campuran antara agregat dan aspal (untuk lapis permukaan lentur) harus mempunyai kepadatan (density) sesuai persyaratan atau spesifikasi yang telah ditentukan.

Permasalahan dalam penelitian ini pengaruh abu sekam padi pada campuran aspal panas AC-WC sebagai pengganti abu batu terhadap parameter Marshall dengan tujuan penelitian ingin mengetahui seberapa besar perbedaan nilai parameter marshall antara abu batu dengan abu sekam padi sebagai pengganti filler pada campuran aspal panas AC-WC.

Stabilitas Lapis Aspal Beton AC-WC menggunakan Abu Sekam Padi-Said Jalalul 
Metode yang digunakan dengan membuat benda uji dari kedua campuran sesuai syarat Depkimpraswil 2002 dengan beberapa variasi tertentu, selanjutnya dilakukan pengujian Marshall dilaboratorium. Penelitian ini hanya melihat perbedaan nilai parameter Marshall antara abu batu dengan abu sekam padi.

\section{Tinjauan Kepustakaan}

Agregat merupakan komponen utama dari struktur perkerasan jalan yaitu 90-95\% agregat berdasarkan presentase berat, atau 75-85\% agregat berdasarkan presentase volume. Dengan demikian kualitas perkerasan jalan ditentukan juga dari sifat agregat dan hasil campuran agregat dengan material lain (Sukirman, 2003). Menurut Bukhari (2004), menyatakan Agregat adalah suatu kumpulan yang kolektif dari pada material-material mineral seperti pasir, kerikil, dan batu yang dipecahkan.

Menurut Sukirman (1999), aspal adalah suatu material yang berwarna hitam atau coklat tua yang pada temperatur ruang berbentuk padat sampai agak padat, jika dipanaskan sampai suatu temperatur tertentu aspal dapat menjadi lunak atau cair sehingga dapat membungkus partikel agregat pada waktu pembuatan aspal beton atau dapat masuk ke dalam pori-pori yang ada pada penyemprotan atau penyiraman pada perkerasan macadam ataupun pelaburan. Jika temperatur mulai turun, aspal akan mengeras dan mengikat agregat pada tempatnya (sifat termoplastis). Beton aspal adalah jenis perkerasan jalan yang terdiri dari campuran agregat dan aspal, dengan atau tanpa bahan tambahan, yang dicampur secara merata atau homogen di instalasi pencampuran pada temperatur tertentu, kemudian diangkut ke lokasi, dihamparkan dan dipadatkan, sehingga terbentuk beton aspal padat. Temperatur pada saat pencampuran ditentukan berdasarkan jenis aspal yang digunakan. Apabila digunakan semen aspal, maka temperatur pada saat pencampuran umumnya berkisar antara $145^{\circ}$ sampai dengan $155^{\circ} \mathrm{C}$, sehingga disebut beton aspal campuran panas atau hotmix.

Menurut Sukirman (2003), lapis Aspal beton adalah beton aspal yang bergradasi menerus, lapis aspal beton (laston) juga sering disebut dengan AC (Asphal Concrete), dan karakteristik beton aspal yang terpenting pada campuran ini adalah stabilitas. Tebal minimum Laston berkisar antara 4-6 cm. Sesuai dengan fungsinya laston mempunyai 3 macam campuran yaitu laston sebagai lapisan aus, dikenal dengan nama AC-WC (Asphal Concrete-Wearing Course) dengan tebal nominal minimum adalah $4 \mathrm{~cm}$, laston sebagai lapis pengikat, dikenal dengan nama AC-BC (Asphal Concrete- Binder Course) dengan nominal minimum adalah $5 \mathrm{~cm}$ dan lataston sebagai lapisan pondasi, dikenal dengan nama AC-Base (Asphal Concrete-Base) dengan tebal nominal minimum adalah $6 \mathrm{~cm}$.

Laston sebagai lapisan aus dikenal dengan nama AC-WC (Asphal ConcreteWearing Course). Tebal nominal minimum AC-WC adalah $4 \mathrm{~cm}$. AC-WC Multigrade, merupakan salah satu implementasi perkembangan teknologi hot mix di Indonesia, dinilai sangat cocok digunakan untuk jalan raya dengan lalulintas berat dan padat/cenderung macet, serta diutamakan untuk digunakan pada daerah tropis. Untuk dapat memikul beban tertentu, suatu material perkerasan harus 
mempunyai kekuatan (strength) atau modulus tertentu. Dan untuk mencapai kekuatan tertentu tersebut, material yang merupakan campuran antara agregat dan aspal (untuk lapis permukaan lentur) harus mempunyai kepadatan (density) sesuai persyaratan atau spesifikasi yang telah ditentukan (Sukirman, 2003).

Sukirman (2003), menyatakan kinerja aspal beton dapat diperiksa dengan menggunakan alat pemeriksaan Marshall untuk menentukan ketahanan (Stabilitas), kelelehan (Flow). Alat marshall merupakan alat tekan yang dilengkapi dengan proving ring dan diliengkapi dengan arloji pengukur yang berguna untuk mengukur stabilitas campuran. Langkah-langkah dalam melakukan pengujian stabilitas dan flow yaitu penentuan kerapatan (density), stabilitas (Stability), pengujian kelelehan (flow), volume pori dalam agregat campuran (VMA), volume pori dalam beton aspal padat (VITM), volume pori antara butir agregat terisi aspal (VFWA) dan perhitungan Marshall Quotient (MQ)

Nugraha (1989), menyatakan abu sekam padi merupakan limbah hasil pembakaran dari sekam padi yang biasanya digunakan sebagai bahan bakar dalam proses pembakaran batu bata mentah, dalam proses pembuatan bata. Sekam padi atau kulit gabah merupakan limbah dari pabrik penggilingan padi di mana sekam merupakan bagian terbesar kedua setelah beras. Dari proses penggilingan gabah akan dihasilkan 16.3\%-28 \% sekam. Abu sekam padi merupakan limbah hasil pembakaran sekam padi. Penggunaan abu sekam padi ini bertujuan sebagai bahan alternative pengganti abu batu (filler) dalam campuran aspal. Hal ini dikarenakan abu sekam padi juga memiliki beberapa unsur kimia yang dikandung oleh abu batu. Adapun komposisi kimia abu sekam padi seperti yang diperlihatkan pada Tabel 1.

Tabel 1 Komposisi Kimia Abu Sekam Padi
\begin{tabular}{|c|c|c|}
\hline No & Senyawa & Presentase $(\%)$ \\
\hline 1 & $\mathrm{SiO}_{2}$ & 92.99 \\
2 & $\mathrm{AL}_{2} \mathrm{O}_{3}$ & 0.18 \\
3 & $\mathrm{Fe} 2 \mathrm{O} 3$ & 0.43 \\
4 & $\mathrm{CaO}$ & 1.03 \\
5 & $\mathrm{~K}_{2} \mathrm{O}$ & 0.72 \\
6 & $\mathrm{Na}_{2} \mathrm{O}$ & 0.02 \\
7 & $\mathrm{MgO}$ & 0.35 \\
\hline
\end{tabular}

Sumber: Nugraha (1989).

Aji (1997), menyatakan berdasarkan komposisi kimiawinya abu sekam padi dapat digunakan sebagai bahan pengisi (filler) dalam campuran aspal. Hal ini dikarenakan komposisi kimiawi abu sekam padi sama dengan silicafume. Silicafume merupakan bahan pozzoalink yang dapat bereaksi dengan $\mathrm{Ca}(\mathrm{OH})_{2}$ atau lime dengan bantuan air untuk membentuk CSH (Calcium Silicate Hydrates) sehingga akan mengurangi kandungan $\mathrm{Ca}(\mathrm{OH})_{2}$ pada beton. Dengan adanya air, silicate dan aluminate membentuk produk hidrasi (hydrates), yang kemudian membentuk massa yang kuat dan keras Reaksi ini cenderung berlangsung lambat.

Stabilitas Lapis Aspal Beton AC-WC menggunakan Abu Sekam Padi - Said Jalalul 


\section{Metode Penelitian}

Bahan atau material yang dipakai untuk beton aspal campuran panas (ACWC) terdiri dari aspal keras AC 60/70, agregat berupa batu pecah, pasir dan sebagai filler. Batu pecah dan pasir berasal dari base camp PT. Cipta Karya Aceh dan filler diganti dengan abu sekam padi yang berasal dari kilang padi sekitar wilayah Aceh Utara.

Perancangan benda uji dikelompokkan dalam 3 bagian, yaitu pertama perancangan benda uji beton aspal campuran panas harus menghasilkan campuran yang baik, untuk itu dipakai gradasi menerus dan rapat seperti disyaratkan dalam spesifikasi Depkimpraswil (2002). Agregat yang dipakai adalah yang lolos saringan mulai dari 3/4", 1/2", 3/8", \#4, dan \#8 sebagai agregat kasar dengan persentase agregat yang lolos sebanyak 54\% dari total agregat. Agregat halus mulai dari saringan persentase agregat yang lolos sebanyak $38 \%$ dari total agregat dan sebagai filler yang lolos saringan No. 200 sebanyak 8\% dari total agregat, seperti pada tabel 2 .

Kedua, benda uji yang dibuat bervariasi berdasarkan kadar aspal optimum (KAO), nilai KAO menjadi patokan untuk membuat variasi benda uji. dengan 3 variasi, yaitu: penambahan filler/abu sekam padi 4\%, penambahan abu sekam padi $6 \%$, dan penambahan abu sekam padi $8 \%$. Dengan kadar aspal 4\%, 5\%, dan $6 \%$, sementara gradasi yang digunakan tetap sama dengan gradasi pada Tabel 2. Variasi berdasarkan kadar aspal dibuat untuk melihat potensi dari jumlah aspal terhadap tingkat stabilitas beton aspal campuran panas. Ketiga variasi kadar aspal pada masing-masing benda uji dibuat sebanyak 3 buah. Variasi dari masingmasing benda uji akan dilanjutkan dengan uji Marshall.

Tabel 2 Spesifikasi agregat bergradasi rapat beton aspal campuran panas

\begin{tabular}{|c|c|c|c|c|c|}
\hline \multicolumn{2}{|c|}{ Saringan } & \multirow{2}{*}{\multicolumn{2}{|c|}{$\begin{array}{c}\text { Spesifikasi } \\
\text { Depkimpraswil (2002) } \\
\% \text { lolos } \\
\end{array}$}} & \multicolumn{2}{|c|}{ \% Lolos } \\
\hline \multirow{2}{*}{$\begin{array}{c}\text { Metrik } \\
(\mathrm{mm})\end{array}$} & \multirow[b]{2}{*}{ ASTM } & & & & \\
\hline & & $\begin{array}{c}\text { Titik } \\
\text { kontrol }\end{array}$ & $\begin{array}{c}\text { Daerah } \\
\text { larangan }\end{array}$ & Tertahan & total \\
\hline 37,5 & $1,5^{\prime \prime}$ & - & & - & \multirow{7}{*}{54} \\
\hline 25 & $1 "$ & - & & - & \\
\hline 19 & $3 / 4 "$ & 100 & & 0 & \\
\hline 12,5 & $1 / 2 "$ & $90-100$ & & 10 & \\
\hline 9,5 & $3 / 8$ & Maks. 90 & & 10 & \\
\hline 4,75 & $\# 4$ & & & 30 & \\
\hline 2,36 & \#8 & $28-58$ & 39,1 & 10 & \\
\hline 1,19 & $\# 16$ & & $25,6-31,6$ & 20 & \multirow{4}{*}{38} \\
\hline 0,60 & $\# 30$ & & $19,1-23,1$ & 7 & \\
\hline 0,30 & $\# 50$ & & 15,5 & 3 & \\
\hline 0,149 & $\# 100$ & & & 5 & \\
\hline 0,075 & $\# 200$ & $4-10$ & & 5 & 8 \\
\hline
\end{tabular}

Sumber: Depkimpraswil (2002)

Stabilitas Lapis Aspal Beton AC-WC menggunakan Abu Sekam Padi - Said Jalalul 
Ketiga, penentuan jumlah benda uji yang dilakukan dengan menentukan kadar aspal tengah $\left(\mathrm{P}_{\mathrm{b}}\right)$, kadar aspal tengah merupakan pedoman untuk membuat benda uji agar diperoleh kadar aspal optimum (KAO) pada suatu campuran. Nilai kadar aspal tengah yang diperoleh dari perhitungan, selanjutnya dibulatkan untuk memudahkan menentukan kadar aspal dalam campuran. Dengan jumlah masingmasing benda uji 3 buah sesuai dengan kadar aspalnya. Penentuan KAO membutuhkan benda uji sebanyak 27 buah. Kadar aspal berkisar antara 4\% - 6\% berdasarkan komposisi beton aspal campuran panas, sehingga dalam menentukan komposisi campurannya adalah dengan menetapkan kadar aspal berdasarkan nilai tengahnya.

Tabel 3 Jumlah benda uji dalam penelitian

\begin{tabular}{|c|c|c|c|c|}
\hline \multicolumn{5}{|c|}{ 1. Perancangan Kadar Aspal Optimum } \\
\hline \multirow{2}{*}{ No Benda Uji } & 4 & 5 & 6 & \multirow{2}{*}{ Kumlah } \\
\cline { 2 - 5 } & 3 & 3 & 3 & 9 \\
\hline Vi & 3 & 3 & 3 & 9 \\
\hline V2 & 3 & 3 & 3 & 9 \\
\hline V3 & \multicolumn{5}{|c|}{ Total } & $\mathbf{2 7}$ \\
\hline \multirow{5}{*}{ No Benda Uji } & Variasi 1 & Vadar Aspal (\%) & \multirow{2}{*}{ Jumlah } \\
\cline { 2 - 4 } & 3 & 3 & Variasi 3 & $\mathbf{9}$ \\
\hline
\end{tabular}

Dalam pembuatan benda uji, aspal yang digunakan harus memenuhi syaratsyarat yang telah ditentukan, sesuai dengan spesifikasi Depkimpraswil (2002). Agregat sebelum dipakai harus dibersihkan, dikeringkan, memenuhi syarat-syarat yang telah ditentukan, dan sesuai dengan gradasi yang diinginkan. Jumlah agregat kasar, agregat halus dan filler adalah 1200 gram untuk setiap benda uji. Campuran agregat kasar, agregat halus dan filler dengan berat yang sesuai dengan rencana campuran dipanaskan hingga temperatur $\pm 160^{\circ} \mathrm{C}$. Aspal dipanaskan sampai pada temperatur pencampuran $\pm 155^{\circ} \mathrm{C}$. Agregat kasar, agregat halus, filler, dan aspal diaduk sampai merata diatas alat pemanas. Setelah merata dimasukkan ke dalam cetakan yang telah dipanaskan, sebelumnya sambil ditusuk-tusuk dengan spatula sebanyak 15 kali pada bagian tepi dan 10 kali pada bagian tengahnya. Selanjutnya dilakukan pemadatan standar pada temperatur $145^{\circ} \mathrm{C}$ dengan alat penumbuk sebanyak 2x75 tumbukan untuk setiap sisinya. Benda uji didinginkan, setelah itu dikeluarkan dari cetakan dengan ejector.

Pengujian ini dimaksud untuk menentukan kekuatan (stabilitas) terhadap kelelehan plastis (flow). Kekuatan adalah kemampuan suatu campuran aspal menerima beban sampai terjadi kelelehan plastis yang dinyatakan dalam kilogram $(\mathrm{kg})$. Kelelehan plastis adalah keadaan perubahan bentuk suatu campuran aspal 
yang terjadi akibat suatu pembebanan sampai batas runtuh yang dinyatakan dalam milimeter (mm).

Karakteristik kekuatan dengan campuran aspal beton dapat diperiksa dengan menggunakan alat pemeriksa Marshall. Pengujian ini dilakukan untuk mengetahui perametr-parameter Marshall campuran aspal berupa stabilitas, kelelehan plastis (Flow), berat isi (Density), rongga dalam butiran (VMA), rongga dalam campuran (VIM), rongga terisi aspal (VFB) dan Marshall Quotient. Setelah benda uji selesai dikerjakan dibersihkan dari kotoran yang menempel diberi tanda sebagai pengenal dan diukur tingginya dengan mistar pengukur, kemudian timbang beratnya dalam timbangan dengan ketelitian 1 gram, dilanjutkan dengan pengujian standar Marshall yang dilakukan dengan merendam benda uji dalam air yang ada pada waterbath selama 30 menit dengan temperatur $60^{\circ} \mathrm{C}$, kemudian dikeringkan permukaannya untuk melakukan pengujian stabilitas dan flow.

\section{Hasil dan Pembahasan}

Dalam pengujian benda uji menggunakan dust, langkah awal pengujian adalah melihat parameter Marshall dan sifat volumetrik dan kadar aspal optimum. Dari hasil pengujian parameter Marshall dan volumetrik dari 3 buah benda uji yang dirata-ratakan diperlihat pada tabel 4 , kadar aspal yang digunakan dalam penelitian ini menggunakan $4 \%, 5 \%$ dan $6 \%$.

Tabel 4 Hasil Parameter Marshall dan Sifat Volumetrik

\begin{tabular}{|c|c|c|c|c|c|c|c|}
\hline $\begin{array}{c}\text { Kadar } \\
\text { Aspal } \\
(\boldsymbol{\%})\end{array}$ & $\begin{array}{c}\text { Density } \\
\left(\mathbf{g r} / \mathbf{c m}^{\mathbf{3}}\right)\end{array}$ & $\begin{array}{c}\text { VMA } \\
\mathbf{( \% )}\end{array}$ & $\begin{array}{c}\text { VITM } \\
\mathbf{( \% )}\end{array}$ & $\begin{array}{c}\text { VFWA } \\
\mathbf{( \% )}\end{array}$ & $\begin{array}{c}\text { Stabilitas } \\
\mathbf{( k g )}\end{array}$ & $\begin{array}{c}\text { Flow } \\
(\mathbf{m m})\end{array}$ & $\begin{array}{c}\mathbf{M Q} \\
\mathbf{( k g / m m})\end{array}$ \\
\hline 4,0 & 2,448 & 18,426 & 2,987 & 83,610 & 1424 & 4,6 & 309,6 \\
\hline 5,0 & 2,389 & 20,000 & 4,809 & 75,541 & 1326 & 4,3 & 313,8 \\
\hline 6,0 & 2,379 & 20,326 & 4,654 & 76,785 & 1763 & 4,0 & 431,4 \\
\hline
\end{tabular}

Tabel 4 Hasil Kadar Aspal Optimum

\begin{tabular}{|c|c|c|c|c|c|}
\hline \multirow{2}{*}{ No } & \multirow{2}{*}{ Kriteria } & \multirow{2}{*}{ Spesifikasi } & \multicolumn{3}{|c|}{ Kadar Aspal (\%) } \\
\hline & & & 4,0 & 5,0 & 6,0 \\
\hline 1 & Density & - & & & \\
\hline 2 & VMA & Min. 15 & & & \\
\hline 3 & VITM & $4,9-5,9$ & & & \\
\hline 4 & VFWA & $>65$ & & & \\
\hline 5 & Stability & 800 & & & \\
\hline 6 & Flow & 2 & & & \\
\hline 7 & $M Q$ & 200 & & & \\
\hline & & & & $5,4 \%$ & \\
\hline
\end{tabular}

Stabilitas Lapis Aspal Beton AC-WC menggunakan Abu Sekam Padi - Said Jalalul 
Kadar aspal optimum diperoleh dengan melakukan pengujian, pertama adalah menentukan kadar aspal tengah dan selanjutnya membuat benda uji dengan kadar aspal tengah sebagai dasar untuk komposisi kadar aspal, kemudian dibuat benda uji dengan kadar aspal kurang dari $1 \%$ serta kadar aspal lebih dari $1 \%$. Setelah itu setiap benda uji di timbang untuk memperoleh volumetrik dan diuji dengan alat Marshall untuk memperoleh parameter Marshall. Hasil diperlihatkan pada Gambar 5.

Berdasarkan nilai parameter Marshall diperoleh nilai KAO 5,4\% dari berat total agregat. Nilai density, VMA, stability, Flow, dan $M Q$ terpenuhi oleh setiap kadar aspal 4\% sampai 6\%, sedangkan VITM dan VFWA yang paling optimum hanya terpenuhi pada kadar aspal 5\%. Nilai interpolasi pada kadar aspal 5,4\% hasilnya dapat dilihat pada Tabel 5.

Tabel 5 Hasil Pencarian Interpolasi

\begin{tabular}{|c|c|c|c|c|}
\hline Indikator & \multicolumn{3}{|c|}{ Kadar Apal 4\%-6\% } & Satuan \\
\hline & $4 \%$ & $6 \%$ & $8 \%$ & \\
\hline Density & 2,389 & 2,402 & 2,369 & $\mathrm{gr} / \mathrm{cm}^{3}$ \\
\hline VMA & 20,196 & 19,723 & 20,665 & $\%$ \\
\hline VITM & 4,716 & 2,392 & 3,545 & $\%$ \\
\hline VFWA & 76,288 & 88,009 & 83,070 & $\%$ \\
\hline Stabilitas & 1587,4 & 1693,2 & 1880,6 & $\mathrm{Kg}$ \\
\hline Flow & 4,12 & 4.48 & 4,62 & $\mathrm{~mm}$ \\
\hline Marshall Qountient & 384,36 & 395,12 & 399,46 & $\mathrm{Kg} / \mathrm{mm}$ \\
\hline
\end{tabular}

Pengujian benda uji menggunakan abu sekam padi ini merupakan hasil dari pengujian langsung terhadap benda uji dengan menggunakan kadar aspal 5,4\% yang didapat dari pencarian nilai KAO.

Tabel 6 Hasil Parameter Marshall dan Sifat Volumetrik

\begin{tabular}{|c|c|c|c|c|c|c|c|c|}
\hline $\begin{array}{c}\text { Variasi } \\
\text { abu } \\
\text { sekam } \\
\text { padi }\end{array}$ & $\begin{array}{c}\text { Kadar } \\
\text { aspal } \\
(\mathbf{\%})\end{array}$ & $\begin{array}{c}\text { Density } \\
\left(\mathbf{g r} / \mathbf{c m}^{3}\right)\end{array}$ & $\begin{array}{c}\text { VMA } \\
(\mathbf{\%})\end{array}$ & $\begin{array}{c}\text { VITM } \\
(\mathbf{\%})\end{array}$ & $\begin{array}{c}\text { VFWA } \\
(\mathbf{\%})\end{array}$ & $\begin{array}{c}\text { Stabilitas } \\
(\mathbf{k g})\end{array}$ & $\begin{array}{c}\text { Flow } \\
(\mathbf{m m})\end{array}$ & $\begin{array}{c}\text { MQ } \\
(\mathbf{k g} / \mathbf{m m})\end{array}$ \\
\hline V1 & 5,4 & 2,430 & 19,951 & 4,652 & 76,724 & 2274 & 4,6 & $\mathbf{5 1 5}$ \\
\hline V2 & 5,4 & 2,461 & 18,951 & 5,222 & 72,447 & 3733 & 5,73 & 656 \\
\hline V3 & 5,4 & 2,481 & 18,279 & 4,615 & 74,750 & 3536,1 & 5,80 & 613 \\
\hline
\end{tabular}

Berdasarkan hasil penimbangan benda uji dan pengujian parameter Marshall dilakukan analisis untuk mengetahui nilai-nilai density, kadar rongga dalam agregat (VMA), rongga terhadap campuran (VITM), rongga yang terisi aspal (VFWA), stabilitas, flow, dan Marshall Quotient. Hasil dari parameter Marshall dan volumetrik dari 3 buah benda uji yang dirata-ratakan diperlihatkan Tabel 7. Kadar aspal yang digunakan dalam penelitian ini menggunakan 4\%, 5\%, dan $6 \%$. 
Tabel 7 Hasil Pengujian Marshall

\begin{tabular}{|c|c|c|c|c|}
\hline \multirow{2}{*}{ Indikator } & \multicolumn{3}{|c|}{ Abu Sekam Padi } & \multirow{2}{*}{ Satuan } \\
\cline { 2 - 4 } & $4 \%$ & $6 \%$ & $8 \%$ & \\
\hline Density & 2,430 & 2,461 & 2,481 & $\mathrm{gr} / \mathrm{cm}^{3}$ \\
\hline VMA & 19,951 & 18,951 & 18,279 & $\%$ \\
\hline VITM & 4,652 & 5,222 & 4,615 & $\%$ \\
\hline VFWA & 76,724 & 72,447 & 74,750 & $\%$ \\
\hline Stabilitas & 2274 & 3733 & 3536,1 & $\mathrm{Kg}$ \\
\hline Flow & 4,6 & 5,73 & 5,8 & $\mathrm{~mm}$ \\
\hline Marshall Qountient & 515 & 656 & 613 & $\mathrm{Kg} / \mathrm{mm}$ \\
\hline
\end{tabular}

Hasil perbandingannya diperlihatkan pada Tabel 8. Perbandingan nilai density pada dust dan abu sekam padi yaitu pada kadar filler $4 \%$ lebih tinggi hasil yang menggunakan abu sekam padi, pada 6\% lebih tinggi yang menggunakan dust, dan pada $8 \%$ nilai density lebih tinggi pada abu sekam padi. Nilai VMA abu sekam padi menurun setiap penambahan persentase. Nilai VMA yang didapat memenuhi spesifikasi Depkimpraswil, untuk nilai VITM-nya tidak memenuhi pada variasi $6 \%$. Volume butir agregat terisi aspal pada abu sekam padi lebih tinggi dari benda uji yang menggunakan dust sedangkan pada 8\% nilai VFWA nya menurun. Untuk nilai stabilitas, flow dan MQ penggunaan abu sekam padi lebih tinggi dibandingkan mnggunakan dust.

Tabel 8 Perbandingan filler (Abu sekam padi)

\begin{tabular}{|c|c|c|c|c|c|c|c|}
\hline \multirow[t]{2}{*}{ Indikator } & \multicolumn{3}{|c|}{ Dust } & \multicolumn{3}{|c|}{ Abu Sekam Padi } & \multirow[t]{2}{*}{ Satuan } \\
\hline & $4 \%$ & $6 \%$ & $8 \%$ & $4 \%$ & $6 \%$ & $8 \%$ & \\
\hline Density & 2,382 & 2,406 & 2,371 & 2,430 & 2,461 & 2,481 & $\mathrm{gr} / \mathrm{cm}^{3}$ \\
\hline VMA & 20,24 & 19,773 & 20,594 & 19,951 & 18,951 & 18,279 & $\%$ \\
\hline VITM & 4,705 & 2,419 & 3,425 & 4,652 & 5,222 & 4,615 & $\%$ \\
\hline VFWA & 76,370 & 87,908 & 83,587 & 76,724 & 72,447 & 74,750 & $\%$ \\
\hline Stabilitas & 1617,33 & 1709,21 & 1917,33 & 2274 & 3733 & 3536,1 & $\mathrm{Kg}$ \\
\hline Flow & 4,1 & 4,5 & 4,7 & 4,6 & 5,73 & 5,80 & $\mathrm{~mm}$ \\
\hline $\begin{array}{l}\text { Marshall } \\
\text { Qountient }\end{array}$ & 392,2 & 397,6 & 400,1 & 515 & 656 & 613 & $\mathrm{Kg} / \mathrm{mm}$ \\
\hline
\end{tabular}

Dari gambar 1 hasil perbandingan antara filler pada campuran dust dan filler abu sekam padi menyatakan bahwa hasil yang didapat ternyata pada filler abu sekam padi lebih tinggi nilai densitynya. Hal ini disebabkan karena filler tersebut mengisi rongga-rongga dalam campuran aspal panas.

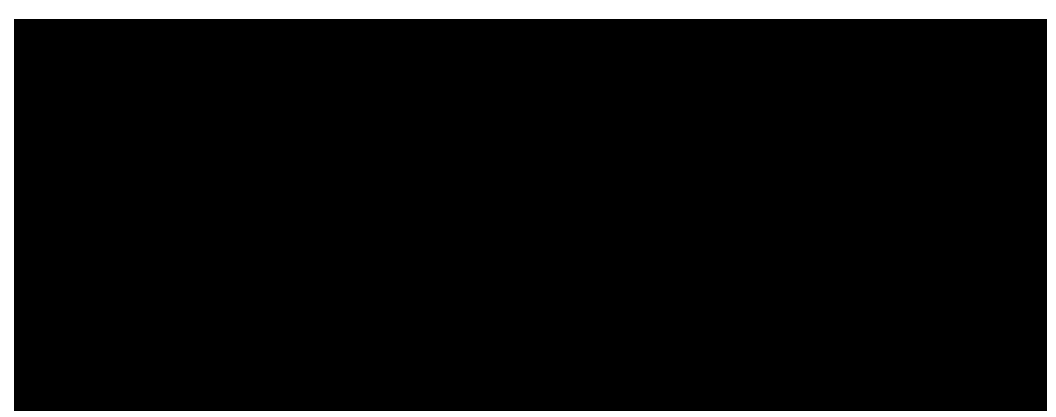

Gambar 1 Perbandingan filler terhadap density

Stabilitas Lapis Aspal Beton AC-WC menggunakan Abu Sekam Padi-Said Jalalul Akbarl), Wesli ${ }^{2}$ 


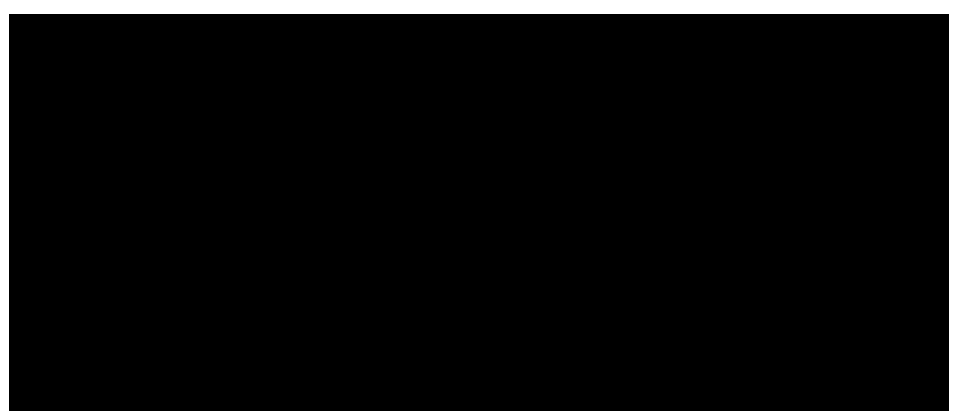

\section{Gambar 2 Perbandingan filler terhadap Stabilitas}

Dari gambar 2 hasil perbandingan antara filler pada campuran dust dan filler abu sekam padi menyatakan bahwa hasil yang didapat ternyata pada filler abu sekam padi lebih tinggi nilai stabilitasnya. Pada kadar filler 4\% campuran abu sekam padi nilai stabilitas sebesar $2274 \mathrm{~kg}$ dan pada campuran dust sebesar $1617,33 \mathrm{~kg}$.

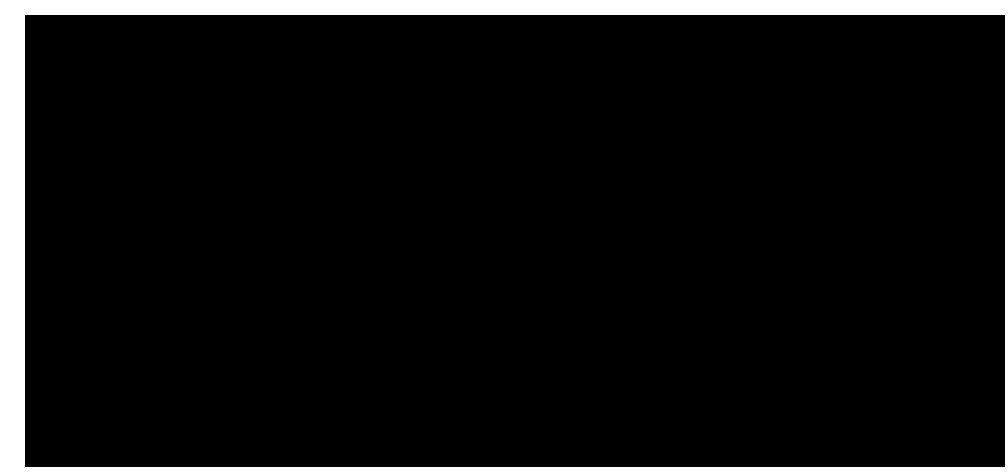

Gambar 3 Perbandingan filler terhadap Flow

Dari gambar 3 hasil perbandingan antara filler pada campuran dust dan filler pada campuran abu sekam padi menyatakan bahwa hasil yang didapat ternyata pada filler abu sekam padi lebih tinggi nilai flownya. Pada kadar filler 4\% campuran abu sekam padi nilai flow sebesar 4,6 $\mathrm{mm}$ dan pada campuran dust sebesar $4,1 \mathrm{~mm}$.

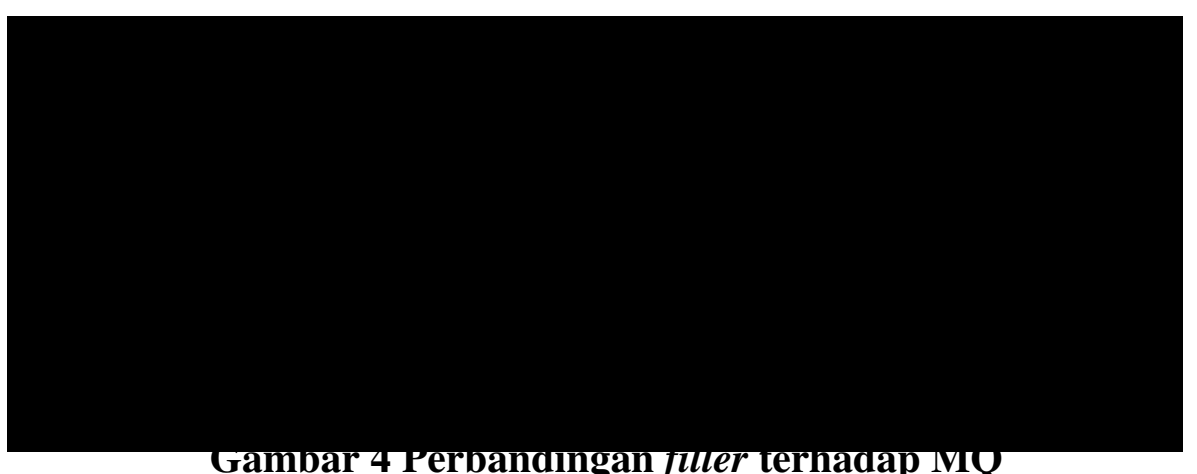

Stabilitas Lapis Aspal Beton AC-WC menggunakan Abu Sekam Padi-Said Jalalul Akbar $^{1)}$, Wesli ${ }^{2)}$ 
Dari gambar 4 hasil perbandingan antara filler pada campuran dust dan filler abu sekam padi menyatakan bahwa hasil yang didapat ternyata pada filler abu sekam padi lebih tinggi nilai $M Q$ nya. Pada kadar filler $4 \%$ campuran abu sekam padi nilai $M Q$ sebesar $515 \mathrm{~kg} / \mathrm{mm}$ dan pada campuran dust sebesar $392,2 \mathrm{~kg} / \mathrm{mm}$.

\section{Kesimpulan dan Saran}

\subsection{Kesimpulan}

Berdasarkan hasil dan pembahasan maka dapat diambil beberapa kesimpulan sebagai berikut:

1. Dari hasil pengujian yang telah dilakukan ternyata nilai Density, Stabilitas, Flow dan Marshall Quotient meningkat (lebih besar) pada campuran yang menggunakan abu sekam padi, bukan pada campuran dust

2. Kenaikan nilai Density, Stabilitas, Flow dan Marshall Quotient secara merata (optimum) terjadi pada campuran yang menggunakan abu sekam padi $6 \%$. Sedangkan pada campuran abu sekam padi 8\% terjadi penurunan nilai stabilitas.

3. Rongga dalam butiran (VMA), rongga dalam campuran (VIM), dan rongga terisi aspal (VFB), terjadi penurunan nilai pada campuran yang menggunakan abu sekam padi.

4. Pemakaian abu sekam padi pada campuran aspal panas AC-WC dapat mempercepat proses penuaan aspal karena abu sekam padi bersifat organik.

\subsection{Saran}

Dari hasil penelitian terhadap penggunaan abusekam padi sebagai pengganti

filler dapat diberikan saran-saran sebagai berikut:

1. Mengingat sulitnya mendapatkan abu batu (dust) yang digunakan sebagai filler pada campuran laston, maka abu sekam padi dapat dijadikan bahan alternatif material jalan sebagai pengganti filler (abu batu)

2. Pada penggunaan abu sekam padi sebagai bahan alternatif material jalan sebagai pengganti filler (abu batu) harus diperhatikan hanya pada campuran maksimal 6\%

3. Perlu dilakukan penelitian yang lebih mendalam agar pemakaian abu sekam padi dapat lebih efektif

\section{Ucapan Terima Kasih}

Penelitian ini terselenggara berkat bantuan saudara Maulida yang dilakukan di Laboratorium P.T Cipta Karya Aceh, Matang Geulumpang Dua Kabupaten Bireun dan sekaligus merupakan Tugas Akhir mahasiswa tersebut yang dibimbing oleh penulis. Pada tempatnya penulis mengucapkan terima kasih banyak atas bantuan dan keterlibatannya dalam penelitian ini.

\section{Daftar Kepustakaan}

1. Aji, 1997, Kajian Pemanfaatan Abu Sekam Padi Sebagai Sumber Listrik, http://fmipa.unipa.ac.id, diunduh tanggal 25 Juli 2010.

Stabilitas Lapis Aspal Beton AC-WC menggunakan Abu Sekam Padi - Said Jalalul 
2. Anonim, 2002, Petunjuk Pelaksanaan Lapis Aspal Beton (LASTON) untuk Jalan Raya, Departemen Permukiman dan Prasarana Wilayah, Direktorat Jenderal Prasarana Wilayah, Jakarta.

3. Bukhari. R. A, Ir. M.Eng, dkk, 2004, Rekayasa Bahan Dan Tebal Perkerasan Jalan Raya, Darussalam, Banda Aceh.

4. Nugraha, 1989, Penambahan Abu Sekam Padi Pada Beton, http://www.jurnal ilmiah teknik sipil.com, diunduh tanggal 25 juli 2010.

5. Sukirman, S., 1999, Perkerasan Lentur Jalan Raya, Nova, Bandung.

6. Sukirman, S., 2003, Beton Aspal Campuran Panas, Granit, Jakarta. 